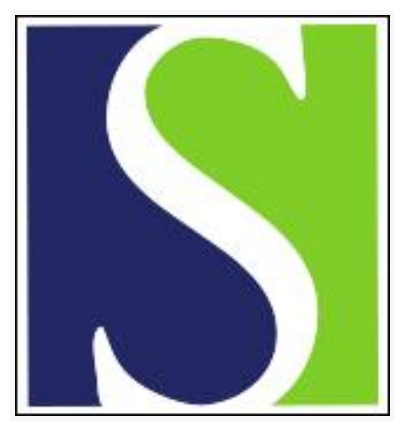

Scand J Work Environ Health 1999;25(6):558-563

https://doi.org/10.5271/sjweh.480

Issue date: Dec 1999

Challenges for the new century in the epidemiology of adult asthma

by Torén $\mathrm{K}$

Key terms: exacerbation; incidence; natural history; occupational exposure

This article in PubMed: www.ncbi.nlm.nih.gov/pubmed/10884153

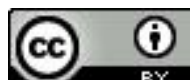




\title{
Challenges for the new century in the epidemiology of adult asthma
}

\author{
by Kjell Torén, $M D^{1}$
}

\begin{abstract}
Toren K. Challenges for the new century in the epidemiology of adult asthma. Scand $J$ Work Environ Health $1999 ; 25(6$, special issue):558-563.

Numerous risk factors are associated with asthma. To achieve adequate precision in epidemiologic studies of asthma, large populations and specific diagnostic methods are to be preferred. The association between air pollution (in a wide sense) and adult-onset asthma is well-known, but little is known about the actual risks. In published studies the fraction of adult-onset asthma caused by occupational exposures ranges from $4.8 \%$ to $36 \%$. Whether subjects with preexisting asthma are at an increased risk for impairment due to asthma when they are exposed to irritants is an issue of great relevance. The literature addressing these problems is scant. The challenge facing us is to design epidemiologic studies on adult asthma that lead to answers to the following questions: (i) has the incidence of asthma increased among adults, (ii) to what extent is adult-onset asthma caused by occupational exposure, (iii) does preexisting asthma get worse due to exposures in the workplace?
\end{abstract}

Key terms incidence, natural history, occupational, exacerbation.

Numerous studies have identified risk factors associated with asthma and hypersensitization. The majority of the high-quality studies have been performed on children (1). Few studies have addressed this important issue for adults (2). There are, however, a few population-based studies indicating that a personal history of hay fever $(3-5)$ is associated with adult-onset asthma, as well as sensitization to both perennial and seasonal allergens (6). Occupational exposures are probably also of major, but underestimated, importance, an issue that is discussed in this paper.

Proper epidemiologic study design in investigations of risk factors of a variable condition, such as adult asthma, presents a challenge to epidemiologists (7). We face similar challenges in the field of musculoskeletal diseases. Current epidemiologic methods are mainly designed for conditions such as death, cancer, or myocardial infarction, conditions with a distinct start, which are often recorded in registers and which are often persistent. Even modern textbooks in epidemiology rarely mention methods to be used in studying variable conditions (8).

\section{Has the incidence of asthma increased among children and teenagers?}

During the last few decades studies have indicated an increased prevalence or cumulative incidence $(9-11)$ or incidence rate (12) of asthma among children and teenagers. The data for such studies have often been obtained from repeated cross-sectional studies. In a thought-provoking paper, Magnus \& Jaakkola (13) have presented a systematic review of repeated cross-sectional studies of asthma and concluded that the evidence for an increased occurrence of this disease among children and young adults is weak. The main problem they identify in repeated cross-sectional studies is changes in diagnostic patterns. Because there has been substantial underdiagnosis of asthma in the population (14), the apparent increase in diagnosed asthma may be a consequence of increased awareness of asthma among physicians. However, Swedish and Finnish studies of conscripts have shown a large increase in the cumulative incidence of asthma, an increase that is hard to explain with diagnostic bias $(9,15)$

Departments of Occupational and Environmental Medicine and Respiratory Medicine and Allergology, Sahlgrenska University Hospital, Göteborg, Sweden.

Reprint requests to: Dr K Torén, Departments of Occupational and Environmental Medicine and Respiratory Medicine and Allergology, Sahlgrenska University Hospital, St Sigfridsgatan 85B, S-412 66 Göteborg, Sweden. [E-mail: Kjell.Toren@ymk.gu.se] 


\section{Has the incidence of asthma increased among adults?}

Another problem with repeated cross-sectional studies has been noted by Järvholm et al (7). They stress that follow-up studies rely heavily on a correct classification of asthma or no asthma at the starting point. Even a slight misclassification of asthmatics as nonasthmatics can distort estimates of the true incidence rate in subsequent follow-up studies, as these "false" nonasthmatics will increase the number of asthmatics in the follow-up.

The published papers regarding the gender-specific incidence of adult asthma have recently been summarized (5). The reviewed papers gave no support to the hypothesis that the incidence of adult asthma has increased in recent decades. In the 2 studies performed in the $1960 \mathrm{~s}$ and $1970 \mathrm{~s}$ the incidence rates among females between the ages of 20 to 60 years ranged between 2 and 5 cases per 1000 person-years, and among the men between 1 and 3 cases per 1000 person-years (5). In studies from the $1980 \mathrm{~s}$ and $1990 \mathrm{~s}$ the incidence rates for women range between 1.1 and 5.2 cases per 1000 person-years, and for males between 0.8 and 3.0. Further evidence is offered by a recent Finnish study showing that the asthma incidence remained constant between 1976 and 1981 and between 1982 and 1990 (16).

\section{Has the natural history of asthma been considered in the design of epidemiologic studies?}

The remission rate and the recurrence rate of adult asthma are not fully understood. However, these rates may provide the basis for risk estimates regarding environmental or occupational exposures and the relapse or remission of asthma among adults. This is an underlying concept when the association between asthma attacks (17) or hospital emergency room visits (18) and ambient concentrations of air pollutants is analyzed. The approach has been successful in environmental epidemiology, but it is rare in occupational settings. One unique occupational study is that by $\mathrm{Hu}$ et al (19), who used these methods to study transistory respiratory symptoms. They investigated 79 borate-exposed workers and 27 control persons over 4 workdays using a questionnaire, measurements of peak expiratory flow, and continuous measure-ments of airborne particulate matter. A field technician sampled the information every hour. The authors then estimated the recurrence rate (new onset of symptoms or person-hours) and showed that borate dust increased the risk for irritation of the nose, eyes or throat in a dosedependent manner. Unfortunately this study has not been replicated, probably because of financial constraints.

\section{Can an epidemiologic diagnosis of asthma be based on self-reporting?}

To achieve adequate precision in epidemiologic studies of adult-onset asthma (or any other rare disease), large populations have to be studied. When risk factors for rare diseases such as adult-onset asthma are analyzed, specific diagnostic methods are to be preferred (20). The question about self-reported physician-diagnosed asthma has been very useful (21), especially in combination with a report of the year of onset $(5,22-24)$. It is a specific, inexpensive, and simple way of diagnosing asthma (21). However, there are some problems linked to this question. This method will probably underestimate the true incidence, which has also been reported previously regarding childhood asthma (4). We recently asked a cohort of 321 clinically well-diagnosed asthmatics to complete a respiratory questionnaire 10 years after their asthma diagnosis (25). In responding to the questionnaire, $10 \%$ denied ever having had asthma. Those who did not recall their asthma had a higher forced expiratory volume in 1 second $\left(\mathrm{FEV}_{1.0}\right)$ and less hyperreactive airways, a finding indicating milder disease (Tunsäter, unpublished manuscript).

The underlying assumption of risk factor studies using self-reporting of asthma is that physicians diagnose asthmatics irrespectively of certain risk factors and that respondents report their disease in the questionnaire regardless of their exposure status. This is not the case among smokers. Among smokers with respiratory problems women are more often labeled asthmatics than men (26). This was, however, only manifest among smokers older than 44 years. Self-reported asthma is probably sensitive to bias with regard to chronic obstructive pulmonary disease (COPD). Hence this working definition is less useful among subjects older than 45 to 50 years of age.

Operational definitions of asthma based on self-reported physician-diagnosed asthma may be useful in epidemiologic studies, but the interpretation of the results must always take into account potential misclassification problems.

\section{How common is asthma caused by occupational exposure?}

The association between air pollution (in a wide sense) and adult-onset asthma has been acknowledged for many years, but surprisingly little is known about the magnitude of the actual risks. The fraction of adult-onset asthma caused by occupational exposures is probably higher than most physicians believe. Increased risks have been recognized in some occupations, as for bakers and 
workers handling laboratory animals. For the general population our knowledge of the total occupational burden has thus far mainly been based upon surveillance schemes, disease registers, and compensation statistics, each of which can use different definitions and different source populations. Hence the patterns have been difficult to interpret and are fraught with inaccuracies and different kinds of biases (27). The proportion of disease that can be attributed to occupational exposures within a population should preferably be assessed by calculating the population attributable risk (PAR) (28). To do this calculation properly, we need population-based studies with control groups that permit us to determine the relative risk associated with occupational exposures. Several studies have been published in recent years (table 1). The estimate of the PAR ranges from $4.8 \%$ to $36 \%$.
Milton has recently discussed some issues regarding the calculation of the PAR for asthma and occupational exposure (28). He points out the well-known fact that, while the relative risk decreases as the definition of exposure becomes less specific, this same trend does not occur in relation to the PAR. This observation was originally made by Wacholder et al (29), who showed that nondifferential misclassification of unexposed subjects as exposed does not change the PAR. On the other hand, if truely exposed subjects are classified as unexposed, the PAR will decrease.

The studies with the lowest estimates of PAR, the Finnish study (30), and the 2 papers from the European Community Respiratory Health Survey (31-32), all use very narrow definitions for the groups at risk. The papers using a broad definition of exposure have the

Table 1. Summary of controlled epidemiologic studies in which the population attributable risk (PAR) due to asthma has been presented or presented data make it feasible to calculate the PAR. ( $N$ = number of asthma cases, $Q=$ =questionnaires, $P D=p h y s i c i a n$ diagnosed, $S R=$ self-reported. BHR=bronchial hypereactivity)

\begin{tabular}{|c|c|c|c|c|c|c|c|}
\hline Reference & Country & $\begin{array}{l}\text { Diagnosis } \\
\text { of asthma }\end{array}$ & Timing & $N$ & Exposure & $\begin{array}{l}\text { Age span } \\
\text { (years) }\end{array}$ & $\begin{array}{l}\text { PAR } \\
(\%)\end{array}$ \\
\hline Rosenman et al, 1997 (40) & Norway & $\mathrm{Q}, \mathrm{PD}$ & Ever & 156 & Gas, dust \& fumes & $15-70$ & 18.9 \\
\hline $\begin{array}{l}\text { Brooks et al, } 1998(41) \text { \& } \\
\text { Wheeler et al (1998 (42) }\end{array}$ & China & $\mathrm{Q}, \mathrm{PD}$ & Ever & 137 & Gas, dust \& fumes & $40-69$ & 12.0 \\
\hline Bakke et al, 1991 (43) & Canada & Q, SR & Ever & 62 & Grain farming & $20-65$ & 14.7 \\
\hline Kogevinas et al, in press (32) & Singapore & Clinical & Current & 787 & A posteriori increased risks & $20-54$ & 33.0 \\
\hline Kogevinas et al, 1996 (31) & Sweden & Clinical & Adult onset & 79 & Gas, dust \& fumes & $20-65$ & 36.0 \\
\hline Wacholder et al, 1994 (29) & Spain & $\mathrm{BHR}+$ symtoms & Adult onset & 136 & A priori increased risks & $20-44$ & 9.0 \\
\hline Reijula et al, 1996 (30) & Finland & Clincal & Adult onset & 8056 & Specific inhalation challenges & $15-64$ & 4.8 \\
\hline Torén et al, in press (24) & Sweden & Clinical & Adult onset & 323 & A posteriori increased risks & $20-65$ & 11.0 \\
\hline Rejula et al, 1996 (30) & $\begin{array}{l}\text { Europe, } \\
\text { United States }\end{array}$ & BHR + symtoms & Adult onset & 702 & A priori increased risks & $20-44$ & 9.9 \\
\hline Forastiere et al, 1998 (44) & United States & $\mathrm{Q}, \mathrm{PD}$ & Adult onset (only women) & 22 & Gas, dust \& fumes & $>55$ & 20.2 \\
\hline
\end{tabular}

Table 2. Summary of controlled epidemiologic studies in which the population attributable risk (PAR) due to wheezing has been presented or presented data make it feasible to calculate the PAR. ( $N=$ number of wheezers, $Q=$ questionnaire, $S B=$ shortness of breath)

\begin{tabular}{|c|c|c|c|c|c|c|c|}
\hline Reference & Country & $\begin{array}{l}\text { Diagnosis } \\
\text { of asthma }\end{array}$ & Timing & $\mathrm{N}$ & Exposure & $\begin{array}{l}\text { Age span } \\
\text { (years) }\end{array}$ & $\begin{array}{l}\text { PAR } \\
(\%)\end{array}$ \\
\hline \multicolumn{8}{|l|}{ Men and women } \\
\hline Xu \& Christiani, 1993 (45) & United States & $Q$ & Persistent & $?$ & $\begin{array}{l}\text { Dusts } \\
\text { Gas, dust \& fumes }\end{array}$ & $25-74$ & $\begin{array}{l}33.2 \\
26.7\end{array}$ \\
\hline Rosenman et al, 1997 (40) & Norway & Q & Ever & 771 & Gas dust \& fumes & $15-70$ & 16.0 \\
\hline Milton \& Christiani, 1997 (46) & United States & Q & Persistent & $\begin{array}{l}250 \\
250\end{array}$ & $\begin{array}{l}\text { Dusts } \\
\text { Gas \& fumes }\end{array}$ & $40-69$ & $\begin{array}{r}0.6 \\
15.7\end{array}$ \\
\hline Bakke et al, 1991 (43) & Canada & Q & Ever & 444 & Grain farming & $20-65$ & 8.2 \\
\hline Wacholder et al, 1994 (29) & Spain & $Q$ & Current & 823 & A priori increased risks & $20-44$ & 2.9 \\
\hline Senthilselvan et al, 1993 (47) & New Zeeland & $Q$ & Current & 48 & A priori increased risks & $20-44$ & 3.1 \\
\hline Korn et al, 1987 (48) & United States & $Q$ & Adult onset & 102 & Manual work & $39-45$ & 37.0 \\
\hline \multicolumn{8}{|l|}{ Men } \\
\hline \multirow[t]{2}{*}{ Xu et al, $1992(49)$} & \multirow[t]{2}{*}{ Italy } & \multirow[t]{2}{*}{$Q$} & \multirow[t]{2}{*}{ Persistent } & & Gas \& dust & & \\
\hline & & & & $\begin{array}{l}41 \\
14\end{array}$ & $\begin{array}{l}\text { Wheeze \& fumes } \\
\text { Wheeze+SB }\end{array}$ & $18-64$ & $\begin{array}{l}14.6 \\
41.7\end{array}$ \\
\hline Fishwick et al, 1997 (50) & France & $Q$ & Ever & 1428 & Gas, dust \& fumes & $25-59$ & 16.9 \\
\hline \multicolumn{8}{|l|}{ Women } \\
\hline Fishwick et al, 1997 (50) & France & $Q$ & Ever & 925 & Gas, dust \& fumes & $25-59$ & 13.4 \\
\hline Bodner et al, 1998 (51) & United States & $Q+S B$ & Current & 175 & Gas, dust \& fumes & $>55$ & 10.2 \\
\hline
\end{tabular}


highest estimates (33-34). According to Wacholder et al (29) and Milton (28) the latter would be closer to the true value, provided that there is no differential misclassification of the exposure. But the assessment of exposure in these studies is based on self-reporting of exposure and may be biased by disease status, that is, exposed subjects with asthma may be more prone to report their exposure to gases, dusts, and fumes than exposed controls are. Table 2 shows the studies which have calculated the PAR for wheezing and occupational exposure. The pattern is the same, with the lowest PAR with a narrow definition of exposure and higher values with a broader exposure definition.

\section{Are subjects with preexisting nonoccupational asthma at increased risk for impairment due to asthma when they are exposed to respiratory irritants?}

This issue is of great relevance, both in clinical practice and when needs for prevention are being identified (35). However, the literature addressing this topic is scant. This exacerbation issue subsumes 2 different clinical scenarios. Workplace exposure may exacerbate currently symptomatic asthma or may trigger a relapse of preexisting asthma in a subject without currently symptomatic disease. But there are several studies showing that environmental exposure to irritants and particles exacerbates preexisting asthma (17-18).

British researchers reported that $31 \%$ of patients with nonoccupational asthma reported impairment due to asthma symptoms on weekdays, as compared with $42 \%$ of patients with occupational asthma (36). This finding indicates that workplace exposure can exacerbate existing asthma. In a community sample of adults with asthma the prevalence of respiratory symptoms at work was about $20 \%$ (37). The same study reported that the prevalence of work-associated respiratory symptoms which later woke the subjects at night was about $10 \%$. These studies indicate that workplace exposure exacerbates impairment in existing asthma. However, neither the bronchial hyperresponsiveness nor the lung function was affected when 12 subjects with current asthma were exposed to high levels of wood dust (38). In a Norwegian study, 25 aluminum potroom workers with asthma-like symptoms were investigated with peak expiratory flow (PEF) and symptom questionnaires (39). They were studied while working with and without respiratory helmets. During the period when the helmets were worn, there was a slight reduction in the prevalence of symptoms and a slight increase in PEF (17.4 1/min).

In case series of patients with suspected work-related asthma, subjects with preexisting asthma seem to be about roughly twice as common as in the general population $(40-42)$. These studies indicate that workplace factors, in particular irritants, can trigger preexisting asthma.

\section{Challenges}

The challenge facing us in the next century is to design and carry out epidemiologic studies on adult asthma that take into account the natural history of the disease. Only then will we be able to answer the following questions:

- Has the incidence of asthma increased among children, teenagers, and adults?

- To what extent is self-reported asthma influenced by differential and nondifferential misclassification?

- To what extent is adult-onset asthma caused by occupational exposures?

- Does preexisting asthma get worse due to exposure in the workplace?

\section{Acknowledgments}

This paper was supported by the Swedish Council for Worklife Research, the Torsten and Ragnar Söderberg Foundation, and Herman Krefting's Fund.

I am also grateful to Drs Lars Barregård, Eva Andersson, and Anna-Carin Olin for their valuable comments.

\section{References}

1. Von Mutius E. The rising trends in asthma and allergic disease. Clin Exp Allergy 1998;28 suppl 5:45-9.

2. Charpin D, Vervloet D, Charpin J. Epidemiology of asthma in western Europe. Allergy 1988;43:481— 92.

3. Broder I, Barlow PP, Horton RJM. The epidemiology of asthma and hay fever in a total community, Tecumseh, Michigan, II: the relationship between asthma and hay fever. J Allergy Clin Immunol 1962;33:524-31.

4. Strachan DP, Butland BK, Andersson HR. Incidence and prognosis of asthma and wheezing illness from early childhood to age 33 in a national British cohort. BMJ 1996;312:1195-9.

5. Torén K, Hermansson B-A. Incidence rate of adult-onset asthma in relation to age, sex, atopy and smoking: a Swedish population-based study of 15813 adults. Int J Tuberc Lung Dis 1999;3:192-7.

6. Sunyer J, Antó JM, Kogevinas M, Barceló MA, Soriano JB, Tobias A, et al. Risk factors for asthma among young adults. Eur Respir J 1997;10:2490—4.

7. Järvholm B, Brisman J, Torén $\mathrm{K}$. The association between epidemiological measures of the occurrence of asthma. Int J 
Tuberc Lung Dis 1998;2:1029-1036.

8. Rothman KJ, Greenland S. Modern epidemiology. 2nd ed. Philadelphia (PA): Lippincott-Raven, 1998.

9. Haahtela T, Lindholm H, Björksten F, Koskenvuo K, Laitinen LA. Prevalence of asthma in Finnish young men. BMJ 1990;301:266-8.

10. Åberg N, Hesselmar B, Åberg B, Eriksson B. Increase of asthma, allergic rhinitis and eczema in Swedish schoolchildren between 1979 and 1991. Clin Exp Allergy 1995;25:8159.

11. Anderson HR, Pottier AC, Strachan DP. Asthma from birth to age 23 ; incidence and relation to prior and concurrent atopic disease. Thorax 1992;47:537-42.

12. Yunginger JW, Reed CE, O'Conell EJ, Melton J, O'Fallon WM, Silverstein MD. A community-based study of the epidemiology of asthma. Am Rev Respir Dis 1992;148:888 - 94.

13. Magnus P, Jaakkola JJK. Secular trend in the occurrence of asthma among children and young adults: critical appraisal of repeated cross sectional surveys. BMJ 1997;314:1795-9.

14. Larsson L, Boethius G, Uddenfeldt M. Differences in utilisation of asthma drugs between two neighbouring Swedish provinces: relation to prevalence of obstructive airway disease. Thorax 1994:49:41-9.

15. Åberg N. Asthma and allergic rhinitis in Swedish conscripts. Clin Exp Allergy 1989;19:59 -63.

16. Huovinen E, Kaprio J, Laitinen LA, Koskenvuo M. Incidence and prevalence of asthma among adult Finnish men and women of the Finnish twin cohort from 1975 to 1990, and their relation to hay fever and chronic bronchitis. Chest 1999; 115:928-36.

17. Rossi OVJ, Kinnula VL, Tienari J, Huhti E. Association of severe asthma attacks with weather, pollen and air pollutants. Thorax 1993;48:244-8.

18. Schwartz J, Slater D, Larson TL, Pierson WE, Koening JQ. Particulate air pollution and hospital emergency room visits for asthma in Seattle. Am Rev Respir Dis 1993;147:826-31.

19. Hu X, Wegman DH, Eisen EA, Woskie SR, Smith RG. Dose related acute irritant responses to occupational exposure to sodium borate dusts. Br J Ind Med 1992;49:706-13.

20. Copeland KT, Checkoway H, McMichael AJ, Holbrook RH. Bias due to misclassification in the estimation of relative risk. Am J Epidemiol 1977;105:488-95.

21. Torén K, Brisman J, Järvholm B. Asthma and asthma-like symptoms in adults assessed by questionnaires: a literature review. Chest 1993;104:600-8.

22. Torén K, Järvholm B, Sällsten G, Thiringer G. Respiratory symptoms and asthma among workers exposed to paper dust: a cohort study. Am J Ind Med 1994;26:489—96.

23. Brisman SJ, Järvholm BG. Occurrence of self-reported asthma among Swedish bakers. Scand J Work Environ Health 1995;21:487-93.

24. Torén K, Järvholm B, Hermansson B-A, Brisman J, Hagberg $\mathrm{S}$, Lillienberg L. Adult-onset asthma and occupational exposures. Scand J Work Environ Health 1999;25(5):00-00.

25. Torén $\mathrm{K}$, Balder $\mathrm{B}$, Brisman J, Lindholm N, Löwhagen $\mathrm{O}$, Palmqvist $M$, et al. The risk of asthma in relation to occupational exposures: a case-control study. Eur Respir J 1999;13:496-501.

26. Dodge RR, Burrows $B$. The prevalence and incidence of asthma and asthma-like symptoms in a general population sample. Am Rev Respir Dis 1980;122:567-75.

27. Nordman H. Occupational asthma - time for prevention. Scand J Work Environ Health 1994;20 special issue: 108 - 15

28. Milton DK. Occupational asthma in New Zealanders: a popu- lation based study. Occup Environ Med 1998;55:215-6.

29. Wacholder S, Benichou J, Heineman EF, Hartge P, Hoover RN. Attributable risk: advantages of a broad definition of exposure. Am J Epidemiol 1994;140:303—9.

30. Reijula K, Haahtela T, Klaukka T, Rantanen J. Incidence of occupational asthma and persistent asthma in young adults has increased in Finland. Chest 1996;110:58-61.

31. Kogevinas M, Anto JM, Soriano JB, Tobias A, Burney P. The risk of asthma attributable to occupational exposures: a population-based study in Spain. Am J Respir Crit Care Med 1996; 154:137-43.

32. Kogevinas M, Antó JM, Sunyer J, Tobías A, Kromhout H, Burney P. A population-based study on occupational asthma in Europe and other industrialised countries. Lancet. In press.

33. Flodin U, Jönsson P, Axelson O. An epidemiologic study of bronchial asthma and smoking. Epidemiology 1995;6:5035 .

34. Ng TP, Hong CY, Goh LG, Wong ML, Koh KTC, Ling SL. Risks of asthma associated with occupations in a communitybased case-control study. Am J Ind Med 1994;25:709-18.

35. Wagner GR, Wegman DH. Occupational asthma: prevention by definition. Am J Ind Med 1998;33:427-9.

36. Axon EJ, Beach JR, Burge PS. A comparison of some of the characteristics of patients with occupational and non-occupational asthma. Occup Med 1995;45:109-11.

37. Abramson MJ, Kutin JJ, Rosier MJ, Bowes G. Morbidity, medication and trigger factors in a community sample of adults with asthma. Med J Aust 1995;162:78-81.

38. De Luca S, Caire N, Cloutier Y, Cartier A, Ghezzo H, Malo JL. Acute exposure to sawdust does not alter airway calibre and responsiveness to histamine in asthmatic subjects. Eur Respir J 1988:1:540—6.

39. Kongerud $\mathbf{J}$, Rambjör Ö. The influence of the helmet respirator on peak flow rate in aluminium potroom. Am Ind Hyg Assoc J 1991;52:243-8.

40. Rosenman KD, Reilly MJ, Kalinowski DJ. A state-based surveillance system for work-related asthma. J Occup Environ Med 1997;39:415-25.

41. Brooks SM, Hammad Y, Richards I, Giovinco-Barbas J, Jenkins K. The spectrum of irritant-induced asthma. Sudden and not-so sudden onset and the role of allergy. Chest 1998;113:42-9.

42. Wheeler S, Rosenstock L, Barnhart S. A case series of 71 patients referred to hospital-based occupational and environmental medicine clinic for occupational asthma. West J Med 1998;168:98-104.

43. Bakke P, Eide GE, Hanoa R, Gulsvik. Occupational dust or gas exposure and the prevalences of respiratory symptoms and asthma in the general population. Eur Respir $\mathbf{J}$ 1991:4:273-8.

44. Forastiere F, Balmes J, Scarinci M, Tager IB. Occupations, asthma and chronic respiratory symptoms in a community sample of older women. Am J Respir Crit Care Med 1998; 157:1864-70.

45. Xu X, Christiani DC. Occupational exposures and physiciandiagnosed asthma. Chest 1993;104:1364-70.

46. Milton D, Christiani D. The risk of asthma attributable to occupational exposures: a population-based study in Spain [letter]. Am J Respir Crit Care Med 1997;155:382.

47. Senthilselvan A, Chen Y, Dosman JA. Predictors of asthma and wheezing in adults. Am Rev Respir Dis 1993;148:66770.

48. Korn RJ, Dockery DW, Speizer FE, Ware JH, Ferris BG Jr. Occupational exposures and chronic respiratory symptoms: a 
population-based study. Am Rev Respir Dis 1987;136:298_ 300.

49. Xu X, Christiani DC, Dockery DW, Wang L. Exposure-response relationships between occupational exposures and chronic respiratory illness: a community-based study. Am Rev Respir Dis 1992;146:413-8.

50. Fishwick D, Pearce N, D'Souza, Lewis S, Town I, Armstrong $\mathrm{R}$, et al. Occupational asthma in New Zealanders: a population based survey. Occup Environ Med 1997;54:301-6.

51. Bodner CH, Ross S, Little J, Douglas JG, Legge JS, Friend
JA, Godden DJ. Risk factors for adult onset wheeze. Am J Respir Crit Care Med 1998;157:35 - 42.

52. Viegi G, Preediletto R, Paoletti P, Carozzi L, di Pede F, Vellutini M, et al. Respiratory effects of occupational exposure in a general population sample in North Italy. Am Rev Respir Dis 1991;143:510—5.

53. Krzyzanovski M, Kaufmann F. The relation of respiratory symptoms and ventilatory function to moderate occupational exposure in a general population. Int $J$ Epidemiol $1988 ; 17: 397-406$ 